\title{
Fatty acid profile and physicochemical, optical and thermal characteristics of Campomanesia adamantium (Cambess.) O. Berg seed oil
}

\author{
David Johane MACHATE ${ }^{1 \star}$ (D), Camila Jordão CANDIDO $^{2}$, Aline Carla INADA², Bruna Callegari FRANCO³, \\ Izabella Renatta Almeida de CARVALHO ${ }^{3}$, Lincoln Carlos Silva de OLIVEIRA ${ }^{4}$, Mário Rodrigues CORTES \\ Anderson Rodrigues Lima CAIRES ${ }^{5}$, Rosa Helena da SILVA ${ }^{1}$, Priscila Aiko HIANE², Danielle BOGO², \\ Nayara Vieira de LIMA ${ }^{6}$, Valter Aragão do NASCIMENTO ${ }^{6}$ (D), Rita de Cássia Avellaneda GUIMARÃES², Arnildo POTT
}

\begin{abstract}
The aim of this study was to characterize the oil obtained from seeds of Campomanesia adamantium by physicochemical quality parameters, oxidative stability, antioxidant activity, quality indexes, optical and thermal stability and its fatty acid profile. These seeds were a relevant source of oil $\left(83 \mathrm{mg} \mathrm{g}^{-1}\right)$ with high potential antioxidant activity $\left(\mathrm{IC}_{50}=25.32 \mu \mathrm{g} \mathrm{mL}^{-1}\right)$ evaluated by DPPH (1,1-diphenyl-2-picrylhydrazyl) with induction period above of 50 hours. In addition, palmitic (53\%) and oleic (34\%) are the primary saturated and monounsaturated fatty acids. This oil showed excellent quality for edible vegetable oil and bioctive compounds. The thermal stability of this oil by thermogravimetric analysis/differential thermogravimetry (TGA/DTG) started at 154 and $231^{\circ} \mathrm{C}$ under synthetic air and nitrogen atmospheres, respectively, and by differential scanning calorimetry (DSC) crystallization was onset at $4.94^{\circ} \mathrm{C}$. This study revealed as a novelty that the $C$. adamantium seeds are an excellent source of oil that presents best qualities, which makes it a great candidate for edible vegetable oil, as well as for production of soap, lotions and biofuel.
\end{abstract}

Keywords: antioxidant activity; Myrtaceae; nutritional quality; oxidative stability; thermal stability; vegetable oil.

Practical Application: Possibility of using of seeds of C. adamantium in human utilization for cooking purpose, as well as for production of soap, lotions and biofuel.

\section{Introduction}

The consumption of fruit species, including seeds or their by-products is widely recommended for human health promotion and disease prevention due to their nutritional properties (Liu, 2013; Ros \& Hu, 2013; Pem \& Jeewon, 2015). Among potential edible plant species is included Campomanesia adamantium (Cambess.) O. Berg (Myrtaceae), found in savannas of South America (Global Biodiversity Information Facility, 2017). Fruits (pulp and including peel) of Campomanesia are widely used for human consumption in natura or utilizing their by-products (Viscardi et al., 2017); however, their seeds are discarded. Nowadays, the search for natural products of plant origin and their whole utilizing in food has increased. That can include seeds of C. adamantium, which oil we obtained.

Oils are composed of several classes of fatty acids classified according to the presence or absence of double bonds in their structure as saturated fatty acids (SFAs-without double bonds), monounsaturated fatty acids (MUFAs-with one double bond) and polyunsaturated fatty acids (PUFAs-with two or up to six double bonds). Besides, as cis or trans based on the configuration of the double bond and as $n-3$ or $n-6$ PUFAs depending on the position of the first double bond of the fatty acid methyl-end (Orsavova et al., 2015; Briggs et al., 2017). Furthermore, MUFAs and PUFAs are highly susceptible to oxidative processes in the presence of heat, light, ionizing radiation, metal ions and metalloprotein, producing free radicals, which lead to rancidity and decrease oil quality, such as off-flavors, loss of color, altered nutrition value, can produce toxic substances, which can impair the health of consumers (Ahmed et al., 2016). Oil quality can be affected during its processing and storage, mainly PUFAs due to their likely degradation by heat, light and atmospheric oxygen actions, including heavy metals (Zhu et al., 2011; Vaskova \& Buckova, 2015). On the other hand, vegetable oils present antioxidants, which slow up or reduce the speed of the oxidation effects in oils, quenching singlet oxygen and reacting or eliminate the free radicals or pro-oxidants, the most frequent in foodstuffs (Kaur et al., 2015).

The current study aimed to determine the fatty acid profile of the oil and its behavior characterization by physicochemical, potential antioxidant activity, nutritional quality, optical evaluation, oxidative and thermal stability analyses.

${ }^{1}$ Programa de Pós-Graduação em Biotecnologia e Biodiversidade, Rede Pro Centro-Oeste, Brasil, Universidade Federal de Mato Grosso do Sul - UFMS, Campo Grande, MS, Brasil

${ }^{2}$ Programa de Pós-graduação em Saúde e Desenvolvimento na Região Centro-Oeste, Universidade Federal de Mato Grosso do Sul - UFMS, Campo Grande, MS, Brasil

${ }^{3}$ Programa de Graduação em Farmácia, Universidade Federal de Mato Grosso do Sul - UFMS, Campo Grande, MS, Brasil

${ }^{4}$ Instituto de Química, Universidade Federal de Mato Grosso do Sul - UFMS, Campo Grande, MS, Brasil

${ }^{5}$ Grupo de Óptica e Fotônica, Instituto de Física, Universidade Federal de Mato Grosso do Sul - UFMS, Campo Grande, MS, Brasil

${ }^{6}$ Grupo de Espectroscopia e Bioinformática Aplicada para Biodiversidade e Saúde, Escola de Medicina, Programa de Pós-Graduação em Saúde e Desenvolvimento na Região Centro-Oeste, Faculdade de Medicina, Universidade Federal de Mato Grosso do Sul - UFMS, Campo Grande, MS, Brasil

*Corresponding author: machatedavidjohanemachate@yahoo.com.br 


\section{Materials and methods}

\subsection{Oil extraction}

We collected the ripe fruits in Campo Grande, MS, Brazil

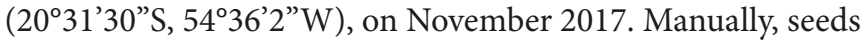
were removed from the fruits, cleaned and immediately dried in an oven under air circulation at $40{ }^{\circ} \mathrm{C}$ during 24 hours. The dried seeds were milled and refined using mortar and pestle. The oil extraction was carried out in ambient temperature by fixed maceration using hexane as a solvent. The supernatant was dried by rotary evaporator and the oil obtained was placed into amber and hermetic glass bottle and stored in a freezer at $-18{ }^{\circ} \mathrm{C}$ for further analysis.

\subsection{Physicochemical characterization}

The acid value was determined by the method Ca $5 \mathrm{a}-40$, refractive index (method Cc 7-25), relative density (method Cc 10a-25), iodine value (method Cd 1-25), saponification value (method Cd 3-25) and peroxide value (method 8-53) according to American Oil Chemists' Society (1990).

\subsection{Antioxidant activity}

The DPPH (2,2-diphenyl-1-picrylhydrazyl) radical scavenging capacity of the antioxidant compound of the oil was investigated in vitro (Wei \& Shibamoto, 2007). The assay tubes were stored in darkness for $60 \mathrm{~min}$. We measured the absorbance in a spectrophotometer (Biochrom Libra S60PC Double Beam, Cambridge, UK) at $517 \mathrm{~nm}$. Ethanol was used as a blank and ethanolic Trolox (( \pm )-6-hydroxy-2,5,7,8-tetrameth ylchromane-2-carboxylic acid) solution as positive. We did the determinations in triplicate. The antioxidant activity was calculated as the inhibition percentage of the DPPH radical (\%AA) as follows (Equation 1):

$\% \mathrm{AA}=\mathrm{Ad}-(\mathrm{As}-\mathrm{Ab}) / \mathrm{Ad} \times 100$

where: Ad = absorbance of the ethanolic DPPH solution; As = absorbance of the mixture of DPPH and sample; and $\mathrm{Ab}=$ absorbance of the blank.

\subsection{Optical analysis: UV-visible and FTIR spectra acquisition}

We diluted the oil in hexane (spectroscopic grade 99.9\%). UV-visible absorption measurements were made utilizing spectrophotometer (Lambda 265 UV/Vis, Perkin Elmer, Waltham, MA, USA) and a quartz cuvette with $10 \mathrm{~mm}$ light path. The UV-visible absorption spectra were collected in the 200-800 nm range. Also, we analyzed the oil by spectrometer FTIR (Thermo Scientific NicoletiS5), obtaining the spectra in the infrared region between $500-4000 \mathrm{~cm}^{-1}$ wavenumber range.

\subsection{Oxidative stability by Rancimat method}

The oxidative stability of the oil was determined according to the European Committee for Standardization (2003) by the Rancimat method utilizing the equipment Rancimat (873 Hersau,
Switzerland). The analyses were performed by adding $3.0 \mathrm{~g}$ of the oil into sealed glass reaction vessel at $110^{\circ} \mathrm{C}$ and analyzing under a constant airflow rate of $10 \mathrm{~L} \mathrm{~h}^{-1}$, which passed through the samples and then into measuring vessel containing $50 \mathrm{~mL}$ ultrapure water Mill-q in which the conductivity generated by volatile products during the oil degradation was measured as a function of time.

\subsection{Methylation and fatty acid profile}

We prepared the fatty acid methyl esters (FAMEs) in ambient temperature (Dodds et al., 2005). The FAMEs were analyzed by (GC 2010, Shimadzu) to obtain their peaks. The equipment used a gas chromatography-Flame ionization detector (GC-FID) and capillary column (BPX-70, $0.25 \mathrm{~mm}$ internal diameter, $30 \mathrm{~m}$ long, and $0.25 \mathrm{~mm}$ thick film). The injector temperature and the detector was $250{ }^{\circ} \mathrm{C}$. The initial column temperature was kept at $80{ }^{\circ} \mathrm{C}$ for $3 \mathrm{~min}$ and then increased at $10^{\circ} \mathrm{C} \mathrm{m^{-1 }}$ and until reaching $140{ }^{\circ} \mathrm{C}$, followed by an increase to $240^{\circ} \mathrm{C}$ at $5^{\circ} \mathrm{C} \mathrm{min}^{-1}$ for $5 \mathrm{~min}$. We identified individual peaks of FAME by comparing their relative retention time with the standard of 37 FAMEs (Supelco C22, 99\% pure).

\subsection{Nutritional quality index}

The nutritional quality of the oil was determined based on its FA composition. The atherogenic index (AI) Equation 2 and the thrombogenic index (TI) Equation 3 considered the MUFA levels (Ulbricht \& Southgate, 1991). The hypocholesterolemic: hypercholesterolemic ratio $(\mathrm{HH})$ followed the Equation 4. The nutritional quality indexes were calculated (Santos-Silva et al., 2002).

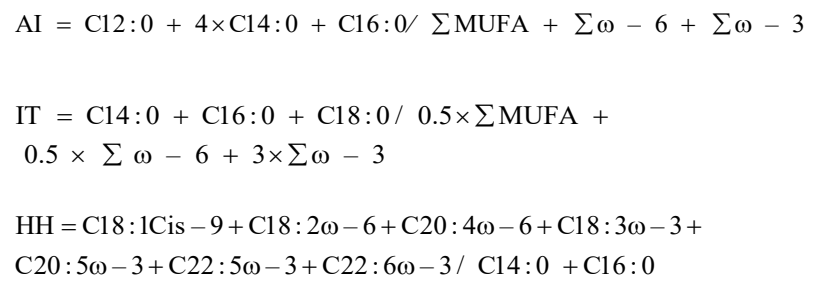

\subsection{Thermogravimetric analysis/ differential thermogravimetry (TGA/DTG)}

A thermobalance TGA Q50, TA Instrument was used. The TGA was calibrated with nickel for temperature settings and with 100 and $1000 \mathrm{mg}$ standards for weight accuracy. Samples $(\sim 3 \mathrm{mg})$ were heated in a platinum pan from 10 to $550{ }^{\circ} \mathrm{C}$ at a heating rate of $2{ }^{\circ} \mathrm{C} / \mathrm{min}$ under nitrogen $\left(\mathrm{N}_{2}\right)$ and synthetic air atmosphere gases $\left(60 \mathrm{~mL} \mathrm{~min}^{-1}\right)$. The data processed by Universal Analyses 2000 software version 3.7A (TA Instruments).

\subsection{Differential Scanning Calorimetry (DSC)}

We obtained the DSC curves in a calorimeter model DSC Q20 with the RCS90 coupled to a cooling system, both TA Instruments. Samples $(\sim 5 \mathrm{mg})$ using aluminium crucibles (Tzero standard) as support and reference, at a heating rate of $10^{\circ} \mathrm{C} \mathrm{min}{ }^{-1}$, cycle heating followed by cooling to temperatures between $-80^{\circ} \mathrm{C}$ and $25^{\circ} \mathrm{C}$, under inert nitrogen $\left(\mathrm{N}_{2}\right)$ atmosphere 
with a flow of $60 \mathrm{~mL} \mathrm{~min}{ }^{-1}$. The data were processed with the help of Universal Analyses 2000 software version 3.7A (TA Instruments).

\subsection{Data analysis}

All experiments were carried out in triplicates. Data were analysed by ANOVA using the R Core Team (R Foundation for Statistical Computing, 2019). The significance of the differences between means for individual acids level were considered at $p<0.001$, and no significant differences observed between classes of acids in this oil $(\mathrm{P}=0.383)$.

\section{Results and discussion}

\subsection{Extraction yield and physicochemical characterization}

The yield oil extraction was $83 \%$, is excellent and is close to Brassica napus L. (Citeau et al., 2018). The physicochemical parameters used demonstrated that the C. adamantium seeds are a source of excellent oil and compared to established conventional parameters and other edible oils (Table 1).

\subsection{Antioxidant activity}

The antioxidant activity of this oil was $\mathrm{IC}_{50}=25.32 \mu \mathrm{g} \mathrm{mL}$, shown to be higher and more effective than Trolox (( \pm )-6-hydroxy2,5,7,8-tetramethylchromane-2-carbonylic acid), a positive control, in a ratio of 1:2. This analysis demonstrated that C. adamantium seed oil is a rich source of natural antioxidant.

\subsection{UV-visible and FTIR}

The UV-Visible absorption spectra found two leading absorbance bands at 236 and $293 \mathrm{~nm}$ (Figure 1), which are related to $\pi$ electronic transitions observed on unsaturations, conjugated nonbonding electron system and aromatic compounds (Spatari et al., 2017). The absorption at $236 \mathrm{~nm}$ may be attributed to different compounds present in the vegetable oil, such as phytocholesterols (phytostanols and phytosterols), tocopherol and others (Gonçalves et al., 2018; Jolayemi et al., 2018). The absorption band at 293 can be attributable to tocopherols and FAs (palmitic, oleic, linoleic and stearic acids) (Lapčikova et al., 2018). Intake of oils rich in phytocholesterols and tocopherols are related with prevention of the cardiovascular diseases, diabetes, obesity, and others (Ogbe et al., 2015; Shahidi \& Camargo, 2016).

The characteristic weak band around at $3006 \mathrm{~cm}^{-1}$ is associated with the higher composition of acyl group of
MUFAs, featured to oleic acid and SFAs (palmitic acid) (Guillén \& Cabo, 1997).

\subsection{Oxidative stability of the seed oil of C. adamantium: Rancimat}

The induction period of the oil was above 50 hours. Higher oxidative stability is attributed to the abundance of the long-chain FAs (99.38\%), higher quantities of palmitic and oleic acids and a smaller amount of PUFAs (5.66\%) (Damanik \& Murkovic, 2018). Beyond to a lower percentage of $\alpha$-linolenic $(0.10 \%)$ compared to linoleic acids (5.56\%) (Damanik \& Murkovic, 2018). Furthermore, this behavior can be attributable to the combination and synergistic interaction of natural several antioxidant compounds, such as tocopherols, tocotrienols, phytostanols and phytosterols (Hassanien et al., 2014; Damanik \& Murkovic, 2018).

\subsection{Fatty acids profile}

We identified a total of nine FAs and their percentages ranging from $0.1 \%$ to $53.02 \%$. Palmitic and oleic are the most abundant fatty acids, as well as has been found in other studies (Renes et al., 2018; Zoidis et al., 2018). Beyond, these two FAs are found in high amount in manufactured edible products using non-conventional processing (Monteiro et al., 2018; Coutinho et al., 2019; Ferreira et al., 2019; Guimarães et al., 2019; Silveira et al., 2019). The FAs profile and the percentage of triglycerides are summarized in Table 2.

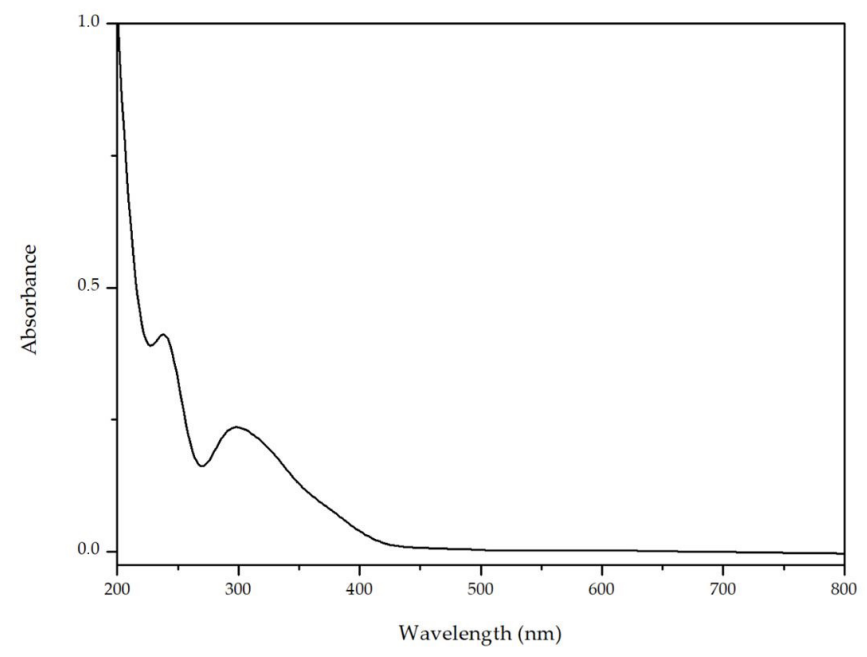

Figure 1. UV-Vis spectra of the Campomanesia adamantium seed oil diluted with hexane in 0.1 .

Table 1. Physicochemical characterization and quality of the Campomanesia adamantium seed oil in comparison with parameters of conventional edible oils.

\begin{tabular}{ccl}
\hline Parameter & C. adamantium & \multicolumn{1}{c}{ Conventional edible oils } \\
\hline Iodine value $\left(\mathrm{gI}_{2} 100 \mathrm{~g}^{-1}\right)$ & $24.95 \pm 18.61$ & Coconut oil (15 \pm 19) (Louheranta et al., 1998) \\
Acid value $\left(\mathrm{mg} \mathrm{KOHg}^{-1}\right)$ & $7.22 \pm 0.26$ & Palm oil (10) (Food and Agriculture Organization of the United Nations, 2001) \\
Saponification value $\left(\mathrm{mg} \mathrm{KOHg}^{-1}\right)$ & 196 & Olive oil (184-196) (Food and Agriculture Organization of the United Nations, 2015) \\
Peroxide value (meq. $\left.\mathrm{O}_{2} \mathrm{~kg}^{-1} \mathrm{oil}\right)$ & 12.93 & $\leq 20$ meq. (Food and Agriculture Organization of the United Nations, 2015) \\
Refraction value at $40^{\circ} \mathrm{C}$ & 1.47 & Olive oil (1.47) (Food and Agriculture Organization of the United Nations, 2015) \\
Relative density at $25^{\circ} \mathrm{C}$ & 0.91 & Olive oil (0.91-0.92) (Food and Agriculture Organization of the United Nations, 2015) \\
\hline
\end{tabular}


Table 2. The fatty acids profile revealed in the Campomanesia adamantium seed oil and their mean and standard deviation (SD) in percentage (\%).

\begin{tabular}{cc}
\hline Fatty acid & Mean \pm SD (\%) \\
\hline Caproic (C6:0) & $0.42 \pm 0.21$ \\
Myristic (C14:0) & $0.20 \pm 0.03$ \\
Palmitic (C16:0) & $53.02 \pm 0.34$ \\
Palmitoleic (C16:1) & $3.97 \pm 0.58$ \\
Stearic (C18:0) & $2.45 \pm 0.84$ \\
Oleic (C18:1 n9c) & $34.13 \pm 0.84$ \\
Linoleic (C18:2 n6c) & $5.56 \pm 0.29$ \\
a-Linolenic (C18:3 n3c) & $0.10 \pm 0.0$ \\
Lignoceric (C24:0) & $0.14 \pm 0.05$ \\
Total SFA & 56.23 \\
Total MUFA & 38.10 \\
Total PUFA & 5.66 \\
Total FAs & 100 \\
\hline
\end{tabular}

SFA $=$ Saturated fatty acid; MUFA = monounsaturated fatty acid; $\mathrm{PUFA}=$ polyunsaturated fatty acid; $\mathrm{FA}=$ fatty acid.

Two FAs (palmitic and oleic) are the majority in C. adamantium oil, which can be used for food applications, soap, lotions and biofuel production (Mba et al., 2015).

This oil present low values of atherogenic (1.23) and thrombogenic indexes (2.52) and high value of hypocholesterolemic: hypercholesterolemic ratio $(0.75)$, which is recommended for human consumption, because they are related to disease prevention and human health promotion (Wood et al., 2008; Fernandes et al., 2018).

\subsection{TGA/DTG}

In both $\mathrm{N}_{2}$ (Figure 2) and synthetic air atmospheres (Figure 3).

The first mass decomposition event temperature can be attributed to the loss of moisture linked by hydrogen bonds of the sample. The second mass loss event is attributable to natural antioxidant decomposition (Juhász et al., 2012; Martins et al., 2012). The third mass loss event is related to FAs of the C. adamantium seed oil.

The presence of one high peak in this oil is explained by the higher percentage of the SFAs and MUFAs, represented by palmitic and oleic acids, respectively compared to PUFA (linoleic and linolenic acids) (Martin-Ramos et al., 2017). The events of this oil in $\mathrm{N}_{2}$ and synthetic air atmospheres are shown in Table 3.

\subsection{DSC}

The DSC curves of the crystallization and melting behavior of the oil are illustrated in Figure 4.

The crystallization temperature of the oil was onset at $4.94^{\circ} \mathrm{C}$, offset $\left(-21.15^{\circ} \mathrm{C}\right)$ and peak enthalpy $(39.24 \mathrm{~J} / \mathrm{g})$. DSC is a crucial technique used to recognize food product features (Farah et al., 2018). The onset crystallization temperature recorded in this study can be explained by the interaction of a higher amount of the SFAs (palmitic and stearic) effect against unsaturated

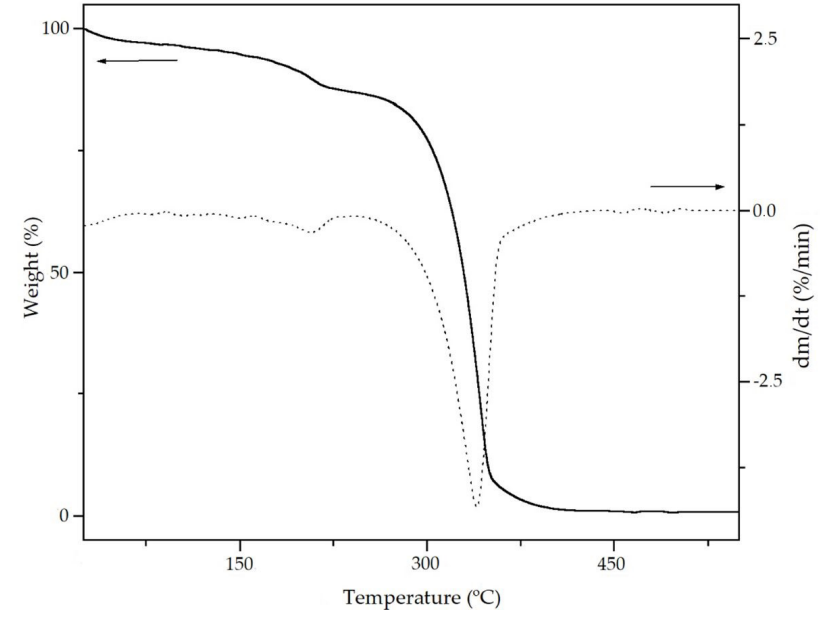

Figure 2. The TGA/DTG curves of the Campomanesia adamantium seed oil at $2{ }^{\circ} \mathrm{C} / \mathrm{min}$ heating from $25^{\circ} \mathrm{C}$ to $550{ }^{\circ} \mathrm{C}$ in nitrogen (N2) air

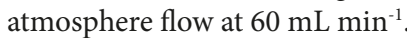

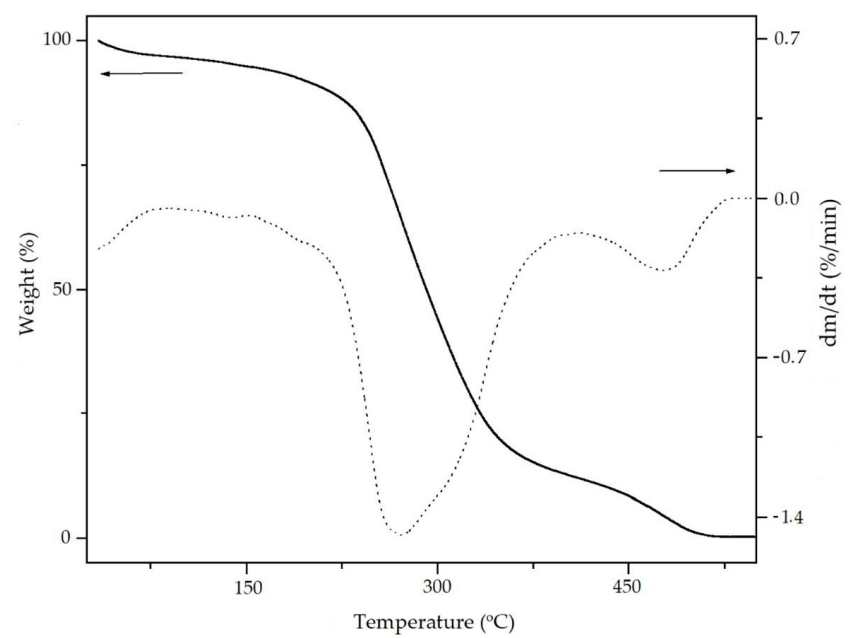

Figure 3. The TGA/DTG curves of the Campomanesia adamantium seed oil at $2{ }^{\circ} \mathrm{C} / \mathrm{min}$ heating from $25^{\circ} \mathrm{C}$ to $550^{\circ} \mathrm{C}$ in synthetic air atmosphere

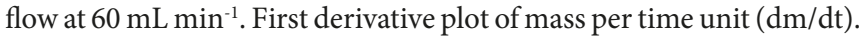

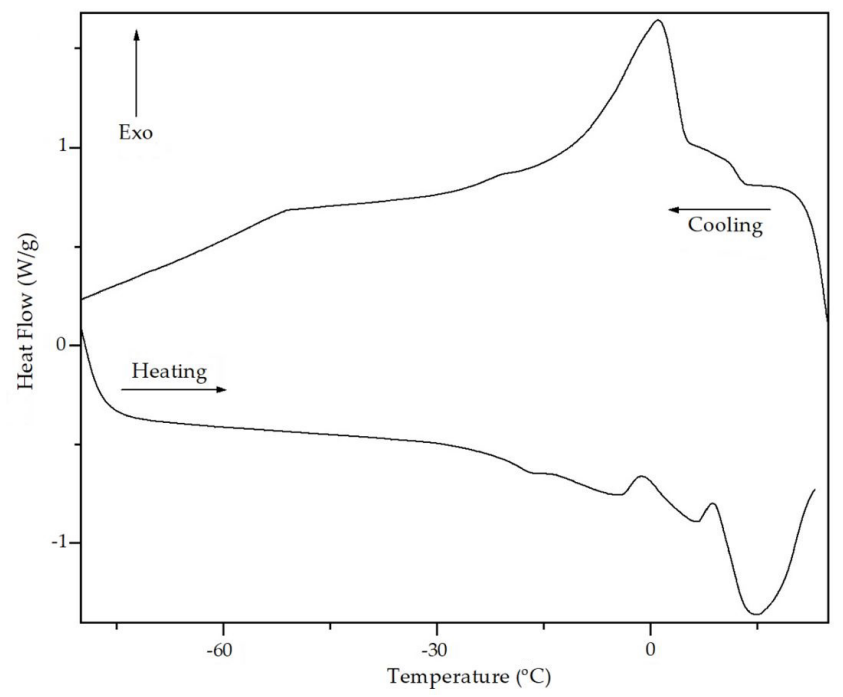

Figure 4. Differential scanning calorimetry (DSC) curves of the Campomanesia adamantium seed oil. 
Table 3. Temperature of mass loss of the Campomanesia adamantium seed oil under nitrogen $\left(\mathrm{N}_{2}\right)$ and synthetic air atmospheres.

\begin{tabular}{|c|c|c|c|c|c|}
\hline \multirow{2}{*}{ Atmosphere } & \multirow{2}{*}{ Event } & \multicolumn{2}{|c|}{ Temperature range $\left({ }^{\circ} \mathrm{C}\right)$} & \multirow{2}{*}{ Event mass loss (\%) } & \multirow{2}{*}{ Residual mass (\%) } \\
\hline & & $\mathrm{T}_{\mathrm{i}}$ & $\mathrm{T}_{\mathrm{f}}$ & & \\
\hline \multirow[t]{3}{*}{$\mathrm{N}_{2}$} & $1^{\text {st }}$ & 89.07 & 160.62 & 2.65 & 0.73 \\
\hline & $2^{\text {nd }}$ & 160.62 & 231.49 & 6.78 & \\
\hline & $3^{\text {rd }}$ & 231.49 & 418.46 & 86.26 & \\
\hline \multirow[t]{2}{*}{ Synthetic air } & $1^{\text {st }}$ & 78.72 & 112.58 & 0.81 & 0.26 \\
\hline & $2^{\text {nd }}$ & 112.58 & 154.31 & 1.51 & \\
\hline
\end{tabular}

$T_{i}=$ Initial temperature; $T_{f}=$ final temperature.

(oleic, linoleic and palmitoleic) acids, as well as the influence of unsaturation on the crystallization temperature of the oil (Rodrigues et al., 2006).

The oil heating behavior was observed at $-13.12^{\circ} \mathrm{C}(3.977 \mathrm{~J} / \mathrm{g})$, $-0.37^{\circ} \mathrm{C}(4.465 \mathrm{~J} / \mathrm{g})$ and $9.41^{\circ} \mathrm{C}(29.95 \mathrm{~J} / \mathrm{g})$, which correspond to PUFAs, MUFAs and SFAs, respectively.

\section{Future studies}

We recommend to future sensory studies of Campomanesia adamantium seed oil as projective methods, sensory description using trained panel and hedonic test with consumer perception of food (Torres et al., 2017; Gambaro, 2018; Vital et al., 2018), as well the determination and characterization of metal and non-metal components in this oil according to the geographical origin (Rocha et al., 2019).

\section{Conclusions}

Campomanesia adamantium seed oil is an excellent source of bioactive compounds whose presence was proven by UV-Visible characterization. Besides, this oil demonstrates high oxidative and thermal stabilities and antioxidant activity, which are directly associated with its excellent quality. The shorter band that appeared at $3006 \mathrm{~cm}^{-1}$ by FTIR analysis and the low iodine value demonstrates that the oil presents a high content of saturated and monounsaturated fatty acids. The lipidic profile confirmed that this oil has similar proportions of saturated and unsaturated fatty acids of which palmitic acid is the major saturated fatty acid while oleic is the monounsaturated fatty acid and presents good nutritional quality. Thus, these qualities found in the $C$. adamantium seed oil make it a great candidate for edible vegetable oil, which can be used for cooking and deep frying food, as well as for production of soap, lotions and biofuel.

\section{References}

Ahmed, M., Pickova, J., Ahmad, T., Liaquat, M., Farid, A., \& Jahangir, M. (2016). Oxidation of lipids in foods. Sarhad Journal of Agriculture, 32(3), 230-238. http://dx.doi.org/10.17582/journal.sja/2016.32.3.230.238.

American Oil Chemists' Society - AOCS. (1990). Official methods and recommended practices of the American Oil Chemists' Society (4th ed.). Illinois: AOCS Press.

Briggs, M. A., Petersen, K. S., \& Kris-Etherton, P. (2017). Saturated fatty acids and cardiovascular disease: replacements for saturated fat to reduce cardiovascular risk. Health Care, 5(2), 1-29. http://dx.doi. org/10.3390/healthcare5020029. PMid:28635680.

Citeau, M., Albe Slabi, S., Joffre, F., \& Carré, P. (2018). Improved rapeseed oil extraction yield and quality via cold separation of ethanol miscella. Oilseeds and Fats, Crops and Lipids |, 25(2), D207. http://dx.doi.org/10.1051/ocl/2018012.

Coutinho, N. M., Silveira, M. R., Fernandes, L. M., Moraes, J., Pimentel, T. C., Freitas, M. Q., Silva, M. C., Raices, R. S. L., Ranadheera, C. S., Borges, F. O., Cucinelli, R. P. No., Tavares, M. I. B., Fernandes, F. A. N., Fonteles, T. V., Nazzaro, F., Rodrigues, S., \& Cruz, A. G. (2019). Processing chocolate milk drink by low-pressure cold plasma technology. Food Chemistry, 278, 276-283. http://dx.doi. org/10.1016/j.foodchem.2018.11.061. PMid:30583374.

Damanik, M., \& Murkovic, M. (2018). The stability of palm oils during heating in a rancimat. European Food Research and Technology, 244(7), 1293-1299. http://dx.doi.org/10.1007/s00217-018-3044-1.

Dodds, E. D., McCoy, M. R., Rea, L. D., \& Kennish, J. M. (2005). Gas chromatographic quantification of fatty acid methyl esters: Flame ionization detection vs. electron impact mass spectrometry. Lipids, 40(4), 419-428. http://dx.doi.org/10.1007/s11745-006-1399-8. PMid:16028722.

European Committee for Standardization - CEN. (2003). Method EN14112: fatty acid methyl esters (fame)-determination of oxidation stability (accelerated oxidation test). Brussels: CEN.

Farah, J. S., Silva, M. C., Cruz, A. G., \& Calado, V. (2018). Differential calorimetry scanning: current background and application in authenticity of dairy products. Current Opinion in Food Science, 22, 88-94. http://dx.doi.org/10.1016/j.cofs.2018.02.006.

Fernandes, I., Nogueira, N., Faria, G., Fernandes, T., Faria, M., \& Cordeiro, N. (2018). Lipid and fatty acid composition of wild almaco jack Seriola rivoliana at two maturation stages. Turkish Journal of Fisheries and Aquatic Sciences, 18(8), 959-967. http:// dx.doi.org/10.4194/1303-2712-v18_8_04.

Ferreira, M. V. S., Cappato, L. P., Silva, R., Rocha, R. S., Guimarães, J. T., Balthazar, C. F., Esmerino, E. A., Freitas, M. Q., Rodrigues, F. N., Granato, D., Cucinelli, R. P. No., Tavares, M. I. B., Silva, P. H. F., Raices, R. S. L., Silva, M. C., \& Cruz, A. G. (2019). Ohmic heating for processing of whey-raspberry flavored beverage. Food Chemistry, 297, 125018. http://dx.doi.org/10.1016/j.foodchem.2019.125018. PMid:31253265.

Food and Agriculture Organization of the United Nations - FAO, Codex Alimentarius. (2001). Codex stan 210-1999: standard for named vegetable oils (pp. 11-25). Rome: FAO/WHO.

Food and Agriculture Organization of the United Nations - FAO, Codex Alimentarius. (2015). Standard for olive and olive pomace oils codex stan 33-1981 named vegetable oils codex stan 210-1999. Rome: FAO/WHO. 
Gambaro, A. (2018). Projective techniques to study consumer perception of food. Current Opinion in Food Science, 21, 46-50. http://dx.doi. org/10.1016/j.cofs.2018.05.004.

Global Biodiversity Information Facility - GBIF. (2017). Campomanesia Ruiz \& Pav. Copenhagen: GBIF. https://doi.org/10.15468/39omei.

Gonçalves, T. R., Rosa, L. N., Gonçalves, R. P., Torquato, A. S., Março, P. H., Gomes, S. T. M., Matsushita, M., \& Valderrama, P. (2018). Monitoring the oxidative stability of monovarietal extra virgin olive oils by UV-Vis spectroscopy and MCR-ALS. Food Analytical Methods, 11(7), 1936-1943. http://dx.doi.org/10.1007/s12161-018-1149-6.

Guillén, M. D., \& Cabo, N. (1997). Characterization of edible oils and lard by Fourier transform infrared spectroscopy. Relationships between composition and frequency of concrete bands in the fingerprint region. Journal of the American Oil Chemists' Society, 74(10), 1281-1286. http://dx.doi.org/10.1007/s11746-997-0058-4.

Guimarães, J. T., Silva, E. K., Ranadheera, C. S., Moraes, J., Raices, R. S. L., Silva, M. C., Ferreira, M. S., Freitas, M. Q., Meireles, M. A. A., \& Cruz, A. G. (2019). Effects of high-intensity ultrasound on the nutritional profile and volatile compounds of a prebiotic soursoup whey beverage. Ultrasonics Sonochemistry, 55, 157-164. http://dx.doi. org/10.1016/j.ultsonch.2019.02.025. PMid:30853535.

Hassanien, M. M. M., Abdel-Razek, A. G., Rudzinska, M., Siger, A., Ratusz, K., \& Przybylski, R. (2014). Phytochemical contents and oxidative stability of oils from non-traditional sources. European Journal of Lipid Science and Technology, 116(11), 1563-1571. http:// dx.doi.org/10.1002/ejlt.201300475.

Jolayemi, O. S., Ajatta, M. A., \& Adegeye, A. A. (2018). Geographical discrimination of palm oils (Elaeis guineensis) using quality characteristics and UV-visible spectroscopy. Food Science \& Nutrition, 6(4), 773-782. http://dx.doi.org/10.1002/fsn3.614. PMid:29983939.

Juhász, M., Kitahara, Y., Takahashi, S., \& Fujii, T. (2012). Thermal stability of vitamin C: Thermogravimetric analysis and use of total ion monitoring chromatograms. Journal of Pharmaceutical and Biomedical Analysis, 59, 190-193. http://dx.doi.org/10.1016/j. jpba.2011.10.011. PMid:22075373.

Kaur, D., Sogi, D. S., \& Wani, A. A. (2015). Oxidative stability of soybean triacylglycerol using carotenoids and Y-tocopherol. International Journal of Food Properties, 18(12), 2605-2613. http://dx.doi.org/10 $.1080 / 10942912.2013 .803118$.

Lapčikova, B., Valenta, T., Lapčik, L., \& Fuksová, M. (2018). Thermal aging of edible oils: Spectrophotometric study. Patravinarstvo Slovak Journal of Food Sciences, 12(1), 372-378. http://dx.doi.org/10.5219/871.

Liu, R. H. (2013). Health-promoting components of fruits and vegetables in the diet. Advances in Nutrition, 4(3), 384S-392S. http://dx.doi. org/10.3945/an.112.003517. PMid:23674808.

Louheranta, A. M., Turpeinen, A. K., Schwab, U. S., Vidgren, H. M., Parviainen, M. T., \& Uusitupa, M. I. J. (1998). A high-stearic acid diet does not impair glucose tolerance and insulin sensitivity in health women. Metabolism: Clinical and Experimental, 47(5), 529-534. http://dx.doi.org/10.1016/S0026-0495(98)90235-9. PMid:9591742.

Martin-Ramos, P., Maria, T. M. R., Correa-Guimaraes, A., CarrionPrieto, P., Hernandez-Navarro, S., \& Martin-Gil, J. (2017). Crude and refined oils from Elaeis guineensis: Facile characterization by FTIR and thermal analysis techniques. International Journal of Food Properties, 20(3), S2739-S2749. http://dx.doi.org/10.1080/1094291 2.2017.1372470

Martins, J. T., Cerqueira, M. A., \& Vicente, A. A. (2012). Influence of a-tocopherol on physicochemical properties of chitosan-based films. Food Hydrocolloids, 27(1), 220-227. http://dx.doi.org/10.1016/j. foodhyd.2011.06.011.
Mba, O. I., Dumont, M. J., \& Ngadi, M. (2015). Palm oil: Processing, characterization and utilization in the food industry-A review. Food Bioscience, 10, 26-41. http://dx.doi.org/10.1016/j.fbio.2015.01.003.

Monteiro, S. H. M. C., Silva, E. K., Alvarenga, V. O., Moraes, J., Freitas, M. Q., Silva, M. C., Raices, R. S. L., Sant'Ana, A. S., Meireles, M. A. A., \& Cruz, A. G. (2018). Effects of ultrasound energy density on the non-thermal pasteurization of chocolate milk beverage. Ultrasonics Sonochemistry, 42, 1-10. http://dx.doi.org/10.1016/j. ultsonch.2017.11.015. PMid:29429649.

Ogbe, R. J., Ochalefu, D. O., Mafulul, S. G., \& Olaniru, O. B. (2015). A review on dietary phytosterols: their occurrence, metabolismo and health benefits. Asian Journal of Plant Science Research, 5(4), 10-21.

Orsavova, J., Misurcova, L., Ambrozova, J., Vicha, R., \& Mlcek, J. (2015). Fatty acids composition of vegetable oils and its contribution to dietary energy intake and dependence of cardiovascular mortality on dietary intake of fatty acids. International Journal of Molecular Sciences, 16(12), 12871-12890. http://dx.doi.org/10.3390/ijms160612871. PMid:26057750.

Pem, D., \& Jeewon, R. (2015). Fruit and vegetable intake: Benefits and progress of nutrition education interventions-narrative review article. Iranian Journal of Public Health, 44(10), 1309-1321. PMid:26576343.

R Foundation for Statistical Computing. (2019). R: a language and environment for statistical computing. Vienna: R Core Team.

Renes, E., De la Fuente, F., Fernández, D., Tornadijo, M. E., \& Fresno, J. M. (2018). Effect of feeding regime non the fatty acid profile of sheep bulk tank milk. International Journal of Dairy Technology, 71(4), 857-867. http://dx.doi.org/10.1111/1471-0307.12553.

Rocha, L. S., Arakaki, D. G., Bogo, D., Melo, E. S. P., Lima, N. V., Souza, I. D., Garrison-Engbrecht, A. J., Guimarães, R. C. A., \& Nascimento, V. A. (2019). Evaluation of level of essential elements and toxic metal in the medicinal plant Hymenaea martiana Hayne (Jatobá) used by Mid-West population of Brazil. Hindwi: The Scientific World Journal, 2019, 4806068. http://dx.doi.org/10.1155/2019/4806068. PMid:31320840.

Rodrigues, J. A. Jr., Cardoso, F. P., Lachter, E. R., Estevão, L. R. M., Lima, E., \& Nascimento, R. S. V. (2006). Correlating chemical structure and physical properties of vegetable oil esters. Journal of the American Oil Chemists' Society, 83(4), 353-357. http://dx.doi. org/10.1007/s11746-006-1212-0.

Ros, E., \& Hu, F. (2013). Consumption of plant seeds and cardiovascular health: Epidemiologic and clinical trial evidence. Circulation, 128(5), 553-565. http://dx.doi.org/10.1161/CIRCULATIONAHA.112.001119. PMid:23897849.

Santos-Silva, J., Bessa, R. J. B., \& Santos-Silva, F. (2002). Effect of genotype, feeding system and slaughter weight on the quality of light lambs. Livestock Production Science, 77(2-3), 187-194. http:// dx.doi.org/10.1016/S0301-6226(02)00059-3.

Shahidi, F., \& Camargo, A. C. (2016). tocopherols and tocotrienols in common and emerging dietary sources: occurrence, applications, and health benefits. International Journal of Molecular Sciences, 17(10), e1745. http://dx.doi.org/10.3390/ijms17101745. PMid:27775605.

Silveira, M. R., Coutinho, N. M., Esmerino, E. A., Moraes, J., Fernandes, L. M., Pimentel, T. C., Freitas, M. Q., Silva, M. C., Raices, R. S. L., Ranadheera, C. S., Borges, F. O., Cucinelli, R. P. No., Tavares, M. I. B., Fernandes, F. A. N., Fonteles, T. V., Nazzaro, F., Rodrigues, S., \& Cruz, A. G. (2019). Guava-flavored whey beverage processed by cold plasma technology: Bioactive compounds, fatty acid profile and volatile compounds. Food Chemistry, 279, 120-127. http://dx.doi. org/10.1016/j.foodchem.2018.11.128. PMid:30611471.

Spatari, C., De Luca, M., Ioele, G., \& Ragno, G. (2017). A critical evaluation of the analytical techniques in the photodegration monitoring of 
edible oils. Lebensmittel-Wissenschaft + Technologie, 76, 147-155. http://dx.doi.org/10.1016/j.lwt.2016.10.055.

Torres, F. R., Esmerino, E. A., Carr, B. T., Ferrão, L. L., Granato, D., Pimentel, T. C., Bolini, H. M. A., Freitas, M. Q., \& Cruz, A. G. (2017). Rapid consumer-based sensory characterization of requeijão cremoso, a spreadable processed cheese: Performance of new statistical approaches to evaluate check-all-that-apply data. Journal of Dairy Science, 100(8), 6100-6110. http://dx.doi.org/10.3168/ jds.2016-12516. PMid:28571992.

Ulbricht, T. L. V., \& Southgate, D. A. T. (1991). Coronary heart disease: seven dietary factors. Lancet, 338(8773), 985-992. http://dx.doi. org/10.1016/0140-6736(91)91846-M. PMid:1681350.

Vaskova, H., \& Buckova, M. (2015). Thermal degradation of vegetable oils: spectroscopic measurement and analysis. Procedia Engineering, 100, 630-635. http://dx.doi.org/10.1016/j.proeng.2015.01.414.

Viscardi, D. Z., Arrigo, J. S., Correia, C. A. C., Kassuya, C. A. L., Cardoso, C. A. L., Maldonade, I. R., \& Argandoña, E. J. S. (2017). Seed and peel essential oils obtained from Campomanesia adamantium fruits inhibit inflammatory and pain parameters in rodents. PLoS One, 12(2), e0157107. http://dx.doi.org/10.1371/journal.pone.0157107. PMid:28222179.
Vital, A. C. P., Santos, N. W., Matumoto-Pintro, P. T., Scapim, M. R. S., \& Madrona, G. S. (2018). Ice cream supplemented with grape juice residue as a source of antioxidants. International Journal of Dairy Technology, 71(1), 183-189. http://dx.doi.org/10.1111/1471-0307.12412.

Wei, A., \& Shibamoto, T. (2007). Antioxidant activities and volatile constituents of various essential oils. Journal of Agricultural and Food Chemistry, 55(5), 1737-1742. http://dx.doi.org/10.1021/jf062959x. PMid:17295511.

Wood, J. D., Enser, M., Fisher, A. V., Nute, G. R., Sheard, P. R., Richardson, R. I., Hughes, S. I., \& Whittington, F. M. (2008). Fat deposition, fatty acid composition and meat quality: a review. Meat Science, 78(4), 343-358. http://dx.doi.org/10.1016/j.meatsci.2007.07.019. PMid:22062452.

Zhu, F., Fan, W., Wang, X., Qu, L., \& Yao, S. (2011). Health risk assessment of eight heavy metals in nine varieties of edible vegetable oil consumed in China. Food and Chemical Toxicology, 49(12), 3081-3085. http:// dx.doi.org/10.1016/j.fct.2011.09.019. PMid:21964195.

Zoidis, E., Poulopoulou, I., Tsoufi, V., Massouras, T., \& Hadjigeorgiou, I. (2018). Effect of terpene administration on goats' milk fatty acid profile and coagulation properties. International Journal of Dairy Technology, 71(4), 992-996. http://dx.doi.org/10.1111/14710307.12529. 